\title{
The Neoliberal Pea and Thimble Trick: Changing Rhetoric of Neoliberal Champions across Two Periods of Economic History and Two Hypotheses about Why the Message Is Less Sanguine
}

\author{
Anthony M. Gould, Mélanie Robert \\ Relations Industrielles, Université Laval, Quebec City, Canada \\ Email: Anthony.Gould@rlt.ulaval.ca
}

Received November $30^{\text {th }}$, 2012; revised December 29 $9^{\text {th }}, 2012$; accepted January $15^{\text {th }}, 2013$

\begin{abstract}
Neoliberalism, or faith in the capacity of markets to solve social and economic problems, is a key element of the prevailing public policy orthodoxy in G20 countries. Throughout the 1980s, key proponents of the Neoliberal message such as UK Prime Minister Margaret Thatcher and American President Ronald Regan spoke optimistically about the philosophy's inevitability and its benefits. During that period, the metaphor of a "rising tide lifting all boats" was offered as a way of envisaging the natural consequence of a supply-side strategy deployed with little or no state intervention. This project examines the shifting neoliberal message through two epochs: the closing decade of the industrial age from approximately 1980 to the early 1990s; and the period of the post-industrial age of e-commerce and the Internet. These eras can be viewed as steps along a path of diminishing comparative commercial advantage for G20 countries relative to emerging economies in Asia, and Latin America. Insofar as neoliberalism is concerned, early proponents of the ideology have realized their objective of reduced state involvement in Western countries but generally have not been able to produce evidence that a "rising tide lifts all boats". Against this background, the modern G20 neoliberal message has changed from being one of optimism, opportunity and growing advantage to being one of survival. This paper explores why the message has changed and offers two interpretations of the relevance of a less bullish view of the advantages of neoliberalism.
\end{abstract}

Keywords: Neoliberalism; Regan; Thatcher; Globalization; Post-Industrial

\section{Introduction}

In 2012 neoliberalism, or the widespread operation of markets with minimal state intervention, is the prevailing public policy orthodoxy in G20 countries. This approach has triumphed in the war of ideas and decision makers mostly view it as a default option for myriad problems. Indeed, within public policies circles it has become unfashionable, or even imprudent, to propose an alternative to the market in matters of social and economic development. Braedley and Luxton (2010) make this point more bluntly. They say,

"Neoliberalism is no longer an alternative to hegemonic political thought as it was in the mid-20th century. It is hegemonic political thought."

(Braedley \& Luxton, 2010: p. 10).

Although widespread embrace of neoliberalism is relatively recent, the idea itself is not new. There is debate about when it first emerged. A milestone date is sometimes cited as 1978 when the California legislature passed Preposition 13 which capped property taxes; an intervention which ultimately caused a funding crisis in higher education (Ong, 2007). In the 1980s neoliberalism, a new and perhaps more refined form of 19th century liberalism, was consolidating itself as a partisan way of approaching public policy. At the time, the views of Margaret Thatcher and Ronald Reagan represented only one perspective amongst a competing array of social and political ideologies. In that era, philosophical approaches to public policy development could be approximately placed on a left-right continuum. In countries like Canada, Australia and New Zealand, the consensus was that elements of the Neoliberal prescription were excessively harsh and generally unsuitable for a national culture which emphasized values such as equality and providing for the socially and economically disadvantaged. However, even for those countries, the market-based solution soon became the mainstream orthodoxy. For example, throughout the 1980s, Australia deregulated product and financial markets (and floated its dollar); abolished tariffs; and corporatized or privatized public utilities such as banking, telecommunications, and, the national airline (Briggs, 2005). These changes were followed by deregulation of the Australian labour market which began in earnest with the 1988 Industrial Relations Act that deemphasized centralized wage-fixing in favour of enterprise-based workplace bargaining over terms and conditions of employment including wages (Hall, 2006). Soon after Australia took its first tentative steps towards installing a market based view of employment relations, New Zealand's conservative Bolger government upped the ante with its Labour Contracts Act (1991). In the aftermath, individual bargaining, lessened union legitimacy, and a watered-down social safety-net became points of reference for future Australian and New Zealand public policy. These elements-individualised wages, a shift from industrial relations to a human resource management perspective, declining union density and increasing income disparity have also become the norm in Britain, Germany, Italy, Japan, Sweden and the United States over approximately the same timeframe (Katz \& Darbishire, 2000). 
Throughout the 1980s as the political spectrum was shifting to the right in the lead-up to globalization, the neoliberal hoopla for working people and the lower-middle class was mostly optimistic. For example, Margaret Thatcher's message was that a market-based approach to delivery of public services would lower costs and, in so doing, free-up disposable income which could then be used-in the form of tax-cuts- to grow the private economy. Her prescription for a better life was not just about privatization but about habitually using the invisible-hand principle to optimize solutions (Braedley \& Luxton, 2010). At the same time, she was encouraging entrepreneurship for those who had only ever worked for others and therefore had entrenched employee status (Connell, 2010). She pushed the message that labour unions - far from furthering the interests of working people-were in fact preventing them from advancing their material circumstances (Connell, 2010). Across the Atlantic, Ronald Reagan, was also vigorously promoting free enterprise. His message was similar to that of his friend, the British Prime Minister: markets are the best strategy for improving the circumstances of ordinary people; a sentiment embodied in President Kennedy's iconic phrase (often repeated in the 1980s) " $A$ rising tide lifts all boats."

Modern champions of free markets say that their operational benefits can only flow in the absence of regulatory influences. However, over the last 30 years, deregulation has been substantially implemented in many sectors of G20 economies, including the labour market, and the neoliberal approach, aided and abetted by the proliferation of technology, is mostly the way things are done. In this article it will be argued that, in circumstances where key elements of the neoliberal agenda are prevailing in public policy, the message offered by neoliberals should, all things being equal, be the same as it always was or evolve to be even more optimistic. According to the axiom if some is good, more should be better, the benefits brought by a ubiquitous market-based approach should flow and compound. However, there is data addressing indices of growing gaps between the rich and the poor and a downward drift of less affluent people living in Western countries (e.g. Kersley et al., 2006; Mishel et al., 2009; Murray, 2012). This article only briefly addresses these. Rather, it argues that neoliberal rhetoric has changed and that the modern message is not the same as the one that was being promoted in the 1980s. Specifically, contemporary neoliberals in G20 countries speak of survival and existence rather than of growth and prosperity. In short, the article argues that the triumph of Neoliberalism in the Western world is associated with a less bullish view of its benefits. It will mostly use examples from the labour market to make the case. In the discussion and conclusion it will present two competing hypotheses about why rhetoric may have changed and offer a methodology for drawing a conclusion about which of these represents the optimal interpretation.

\section{Neoliberal Rhetoric: Its Antecedents and Its More Recent Metamorphosis}

Neoliberalism is an approach to public policy founded on the idea that the unbridled operation of markets is the most efficient and ethical way to distribute the aggregate benefits of society's effort (Braedley \& Luxton, 2010). The philosophy has elsewhere been viewed as a project to visualize a free-market utopia involving the downsizing of the nation state to enlarge the space for private accumulation, individual entrepreneurial ac- tion and, the operation of the principle of the market (Tickell \& Peck, 2003). This view has been consolidated as antithetical to socialism; a philosophy which is sometimes perceived as restricting freedom, redistributing wealth in arbitrary and inefficient ways, and limiting the expression of human potential in an effort to unburden individuals from economic necessity (Hayek, 1944). Neoliberalism echoes the sentiments of classical 18th and 19th century liberalism as espoused by philosophers such as De Toqueville, Hume, Locke and Smith. Indeed, there is such similarity between modern Neoliberalism and its predecessor ideology that it is reasonable to ask whether neoliberalism really is "neo" in any meaningful sense or whether it is better described as old wine in new bottles.

Those who view neoliberalism disdainfully often point out that that there is a disconnect between liberalism and neoliberalism. For example, Brodie (2007) says neoliberalism takes the principle of the market to facets of life where it does not belong; drinking water, air for breathing, playgrounds for children and even body parts and the management of outer space. There are studies which provide empirical evidence that, at least in relation to certain assets, markets hinder access, exacerbate inequality and do not advance the public good (e.g. Mishel et al., 2009). On the other hand, certain scholars, such as those from the Chicago School of Economics including the late Milton Friedman, appear to genuinely believe that markets are inevitably, and in all cases, the preferred way of efficiently apportioning benefits. Neoliberal proponents are frequently first and foremost critiques of socialism. The substance of their rhetoric is often better described as intuitively appealing macro-philosophy rather than reports of empirical findings (Braedely \& Luxton, 2010: p. 11).

Critiques of neoliberalism do not only come from analysts who demonstrate with data that the theory doesn't translate well into practice. There are also cynics; scholars who consider that neoliberalism does not qualify as an economic theory but merely is a strategy that wealthy people use to advance their interests. For example, economist Joseph Stiglitz says

"Neo-liberal market fundamentalism was always a political doctrine serving certain interests. It was never supported by an economic theory. Nor, it should now be clear, is it supported by historical experience. Learning this lesson may be the silver lining in the cloud now hanging over the global economy"

(Stiglitz, 2008).

In this article, Neoliberalism ${ }^{1}$ is viewed as distinctively modern (and therefore not the same as liberalism) in the sense that it ruthlessly applies the principle of the market as ubiquitously as possible and, in particular, as a remedy for social problems such as poverty and inequality. According to this perspective a point of discontinuity between liberalism and neoliberalism concerns the commodification of labour. The 19th century liberals, despite their extensive discussion of division of labour and their use of language which characterized factory workers as inputs into the production process, did not focus their efforts on the supply and demand dynamic — of what is now identified as - a labour market (Duncan, 1999). On the other hand, in the modern western world neoliberals push to deregulate labour markets and have mostly won debate about this issue. In the 30 years prior to 2012 in G20 countries there is a trend towards less State intervention in the employment relationship and towards, what Hall (2006) calls, a market-based approach. Mod-

${ }^{1}$ Sometimes called supply-side or trickle-down economics when referring to its predicted effects on the disadvantaged. 
ern neoliberals, in keeping with their broader philosophy, suggest that wages in the long term can only be set by market forces and are limited ultimately by a society's level of affluence. In taking the view that neoliberalism is different to liberalism, this article does not take exception to Neoliberalism as a sound guiding principle for developing public policy ${ }^{2}$. Rather it focuses on examining how the message has been changing over the last 30 years and draws conclusions about why such change is occurring.

Since the 1980s, the neoliberal message has become simultaneously more ubiquitous and more sanguine. There appear to be three main influences on this phenomenon. First, neoliberal policies have been applied to a greater range of public services within G20 countries. Second, proponents of neoliberalism have attenuated their message about the advantages of the approach. Third, neoliberal philosophy, particularly in the 1990s, became intertwined with technological advances. For example, as a consequence of the Internet and Internet-based technologies, there emerged a new and non-ideological impetus for the State's role to become more marginalized. Specifically, it was becoming more difficult for jurisdiction-bound governments to regulate commerce.

\section{The Proliferation of Neoliberal Policies}

Neoliberalism has been gaining traction since the 1980s and, in more recent times, has had the serendipitous advantage of promoting a message that is well adapted to a context of borderless trade (Cerny, 2007). The Neoliberal project has taken different forms throughout the world but has, at its core, distinctive elements which are increasingly present in public policy. These include economic deregulation, the displacement of traditional state forms, and the reorganization of economic activity guided by the maxim that the apparatus of government is constraining and negative (Rainnie \& Fairbrother, 2006).

The implementation of Neoliberal policy in G20 countries mostly started with deregulation of capital and financial markets but more recently has become a quest to broaden existing markets and create new ones. Along the way-and as part of the agenda-government assets and institutions have become privatized. For example in Australia, the national airline, telecommunications carrier, bank and wheat marketing system have been reestablished as publicly listed companies and floated on the stock exchange. Similar trends have occurred in New Zealand, Canada and Great Britain where key national assets have been privatised and launched into increasingly deregulated oligopolistic industry structures (Katz \& Darbishire, 2000). Even where privatization has not occurred, a market-based approach has replaced earlier notions of public service. For example, in the education sector of most G20 countries statebased subsidies have been used to establish public and private schools on an equal-footing with the goal of forcing all institutions to compete for students and funds. At the same time, public universities have been defunded and forced to levy fees (Marginson, 1997). Similar strategies have been applied with welfare where service provision is now routinely put out for tender and public agencies that formerly provided the function now compete with non-government entities (Braedely \& Luxton, 2010). These kinds of approaches have been adopted with healthcare and public housing (Braedely \& Luxton, 2010). To

${ }^{2}$ Something which has been done by others such as Braedely \& Luxton (2010). support trade liberalization and financial and capital market deregulation, Western governments have mostly unified their exchange-rates, lowered taxation (and simplified tax systems), reduced spending, introduced labour flexibility initiatives and dismantled social safety nets (Tickell \& Peck, 2003).

\section{The Changing Message}

This article's principal message is that Neoliberal rhetoric has changed since the 1980s. In particular, a qualitatively differing message has emerged from approximately the early 1990s and, hence, two distinctive eras are discernible: the closing years of the industrial age; and, the first two decades of the post-industrial age.

In the last part of the industrial-age, neoliberalism within G20 countries was one putative solution amongst others which generally could be arranged on a left-right axis. Insofar as the labour market was concerned, countries such as New Zealand, Canada, and Australia, adopted either a liberal reformist or orthodox pluralist perspective of the employment relationship in the early 1980s. Public policy of the time placed emphasis on elimination of inequality and injustice or, at least, balancing efficiency considerations with notions of equity and social justice (Godard, 2011). In the 1990s, debate shifted to being about whether managerialism was unduly extreme. On the other hand, the neoliberals of the 1980s in the western world had a couple of high profile leaders, such as Margaret Thatcher and Ronald Regan, who were both heads of government and ideological figureheads. Their message was up-beat and confident. It was marketed as an assured path to rising prosperity for everyone, including the very poor. It typically included two elements. First, the market solution generally leads to greater prosperity. Second, such greater prosperity will impact the lives of each social/economic class. A third, and perhaps less explicit, article of neoliberal faith during the 1980s was that rising levels of wealth will differentially benefit each social strata; the rich will become much richer and the poor only a little bit more affluent. Put more technically, the dividend of economic growth is shared but not in equal increments ${ }^{3}$. These three elements are overtly present in the following quotes which come from the stalwarts of the 1980s.

"Growth, of course, is not enough. It must be the vehicle of a better standard of living for all the people. Again, economic and political freedom are inseparably linked".

Ronald Reagan, (August 3, 1987).

In this context growth was identified as resulting from the unbridled application of the market principle.

A key theme of Regan's second inaugural address was that markets are a solution to social problems and represent a strategy for making the lives of ordinary people better.

"And if we meet this challenge, these will be years when Americans have restored their confidence and tradition of progress... when America courageously supported the struggle for individual liberty, self-government, and free enterprise throughout the world and turned the tide of history away from totalitarian darkness and into the warm sunlight of human freedom."

"At the heart of our efforts is one idea vindicated by 25 straight months of economic growth: Freedom and incentives unleash the drive and entrepreneurial genius that are the core

${ }^{3}$ Neoliberals do not generally see rising inequality as a problem if it occurs in a context where everyone's material circumstances are improving (Braedley \& Luxton, 2010). 
of human progress. We have begun to increase the rewards for work, savings, and investment; reduce the increase in the cost and size of government and its interference in people's lives. We must simplify our tax system, make it fairer and, bring the rates down for all who work and earn."

"We must think and move with a new boldness, so every American who seeks work can find work, so the least among us shall have an equal chance to achieve the greatest things-to be heroes who heal our sick, feed the hungry, protect peace among nations, and leave this world a better place. The time has come for a new American emancipation-a great national drive to tear down economic barriers and liberate the spirit of enterprise in the most distressed areas of our country".

Ronald Regan. Second Inaugural Address (January 21, 1985).

At about the same time, Great Britain's Margaret Thatcher said.

"The only one way to get prosperity and a higher standard of living in this country is to get our industries running as efficiently as any of those in the rest of the world."

Margaret Thatcher (January 16, 1985).

During the 1980s the exuberance of Neoliberal rhetoric from its British and American champions influenced the policy direction of non-conservative governments in Australia, New Zealand and Canada. These countries had not emphasised the market solution as always and inevitably being the best public policy option. For example, in 1983 the incoming Australian labour government mostly resisted the market solution in key facets of public policy. Indeed, Bob Hawke's first accord has been viewed as an explicit way of avoiding exposure to the market (Gould, 2010; Hall, 2006). Similarly, in New Zealand, during the time of the Lange government, the Prime Minister repudiated the previous government's flirt with privatization. Early in his term, he said

"The election of a labour Government has ended the move towards privatisation of state ventures by the National Government."

\section{David Lange (1984).}

However, possibly influenced by Regan and Thatcher, the Australian and New Zealand Labour governments of the 1980s appeared to move towards embrace of the neoliberal message during the first few years of their mandates ${ }^{4}$. Like their more zealous American and British counterparts, these leaders did not speak about maintenance of a standard of living or survival in a zero-sum world arena. Rather, perhaps spurred by strong economic growth in the late 80 s in particular, they ultimately spoke of making the cake bigger. The emerging idea was that neoliberalism is the way of the future; not because there is no choice but rather because-it presents a great opportunity to make things even better. Specifically, the changing rhetoric of labour leaders such as Australia's Bob Hawke and New Zealand's David Lange, embodied the aforementioned two elements; markets improve lives and the advantages that markets bring are shared, albeit unevenly, amongst everyone. For example:

"There is quite wide appreciation within Australia that it will be necessary gradually to reduce Australian protection levels if we are to achieve the goal of a more efficient, export-oriented

${ }^{4}$ It is not suggested here that this was the only influence. Another key justification for enhanced emphasis on the principle of the market was the mid-1980s terms of trade crisis which saw Australia and New Zealand becoming less competitive internationally (Gould, 2010). manufacturing sector".

Bob Hawke (February 4, 1984).

In a speech to Centre for European Policy Studies, Hawke said also

"From Australian Industry we seek acceptance of the need to reduce protective walls around the small domestic market. And in this we have had some success. It is enlightened self-interest to recognize that protective measures impose a cost for the economy as a whole. They put upward pressure on prices in the protected market and through the rigidities and distortions which they introduce they ultimately reduce employment and export opportunities. We have to break loose from the notion, inherent in the negotiation framework, that one's own trade liberalization is concession granted to others.”

Bob Hawke (February 4, 1985).

Across the Pacific, New Zealand's David Lange—soon after being elected-was also changing his tune about neoliberalism. For example, he said in 1984 that

"It has been decided that New Zealand has no business being run like a Central European (i.e. Socialist) economy, and that the Government departments and activities will be progressively sold and privatised. The sale proceeds will be used to pay off the National (overseas) debt and, in so doing, enhance our opportunities."

David Lange (1984).

At about the same time, members of Lange's cabinet were echoing similarly optimistic sentiment about markets, deregulation and small government. For example, Richard Prebble, the Minister of State-Owned Enterprises, used the sale of stateowned assets as a means of retiring debt. He said that the resulting efficiency-gains would be given back to taxpayers and translated into overall enhanced prosperity (Prebble, 1984).

Like Hawke and Lange, Jean Chrétien, Canada's Prime Minister, went from being an opponent to a convert of the neoliberal cause. His conversion was accompanied by optimism and enthusiasm.

"Notre gouvernement est persuadé que la libéralisation des échanges est le levier international le plus efficace qui soit pour promouvoir l'emploi et la croissance. Notre pays est tributaire de ses exportations. Notre prospérité future dépend de la capacité qu'ont les gens des autres pays d'acheter ce que nous produisons. C'est pour cette raison que le commerce a été-et continuera duêtre-tout aussi prioritaire pour nous. Et ce n'est pas seulement prioritaire pour notre pays, pour les membres du G7 ou pour les pays industrialisés. Cela est prioritaire pour tous les pays." and "On ne peut pas faire fi de la technologie. On ne peut pas effacer les trente dernières années. On ne peut pas avoir la nostalgie du bon vieux temps. Il faut faire face aux réalités actuelles.”

Jean Chrétien (June 14, 1995).

In the post-industrial era and in particular since 2008's financial crisis, the neoliberal message has become simultaneously more mainstream and less optimistic. Contemporary neoliberals present the principle of the market as the last hope for G20 countries to maintain the status-quo. In the 15 years prior to 2012, the message about free and deregulated markets has typically centered on three elements. First, the Western standard of living is deteriorating and/or under threat. Second, those who have promoted state intervention throughout the 20th century have created the crisis or, at a minimum, made countries less able to cope with it. Third, an unbridled emphasis on markets is the only hope of saving the West. Notions of improving 
material circumstances and/or bettering living standards is conspicuously absent from the narrative. These three elements are present in the following quotes which come from Western leaders during the 1990s and early part of the 21st century.

"(Australia) needs a new style of government, one which acts strongly within the realms of the possible, one with a disposition towards individuals finding their own solutions... Only in this way will we have the strength to face the future, to face the challenges of globalization."

John Howard, Australian Prime Minister when speaking about globalization and limited government (Howard, 1997 cited in Shanahan, 1997).

"... at the heart of the public policy towards the new economy is the idea that helping people... is not about protection but empowerment. The pace of reform has to match the pace of change. Societies that are open, flexible, able easily to distinguish between fundamental values which they must keep and policies which they must adapt, will prosper. Those that move too slowly or are in hock to vested interests... will fall behind... and because they will, the task of New Labour in power is clear... Supporting wealth creation. Tackling vested interests. Using market mechanisms."

Tony Blair, British Prime Minister (January 28, 2000).

"But you know look, times are going to be pretty tough over the next three years, our ability to spend up large in our budgets is very heavily reduced, I mean it's largely nonexistent. We'll be spending under half what the government has spent in the last four or five years for new budget spending initiatives. So we are going to need to stop some programs and find some savings in order to fund some new initiatives that the government believes are very important."

John Key, New Zealand Prime Minister (December 12, 2008).

\section{The Changing Context}

As the industrial age was replaced by the Internet-enabled post-industrial era, there emerged new reasons why it would be more difficult, in practice, for national governments to regulate markets and constrain commercial activity. At about this point, those who had been neoliberal ideologues were confronted with an altered context and, in particular, the prospect of incorporating overseas trading partners into their conception of the private sector. For G20 countries, the terrain was formally altered in two ways. First, they were henceforth to deal with less affluent nations with lower cost structures and vast populations (Wailes, 2000). These poorer countries, such as India and more recently China and Indonesia, were industrializing and/or emerging from centrally planned and controlled economies (Bamber, et al., 2011). Second, the idea of a Western national government regulating commercial activity was beginning to seem less practical; a phenomenon which is elsewhere identified as marginalization of the nation-state (Katz \& Darbishire, 2000). In short, advances in communications and computing technology combined with previous ideological exuberance on the part of charismatic leaders seemed to be moving the market-principle from the far-right of the political spectrum into the center. Countries had been pre-primed for neo-liberalism and the arrival of the Internet transformed the philosophy from an apparently attractive option into seemingly the only option. As part of this transformation, neoliberal heroes such as Thatcher and Reagan became historical visionaries without a modern equi- valent.

A weakened concept of jurisdiction-based authority as a result of e-commerce based strategies creates methodological problems in determining whether neoliberalism can deliver on its promises. Globalization has created a milieu where markets and supply-chains extend across national borders. Insofar as individual countries are concerned, local cultures and lifestyles are being, at least, influenced by systems of economic exchange which bind together parties which have different standards of living, cost structures, and expectations (Kochan et al., 1997). This context makes longitudinal comparisons of the neoliberal message inapt. For example, it would be misleading to compare the impacts of labour market deregulation pre-NAFTA on American auto-workers with how it affects the average of American and Mexican auto-workers post-NAFTA. The object of analysis would be different in each of these cases and, in the short-term, there may be catch-up for the relatively poorer group, a phenomenon that has sometimes been described as the race to the rising bottom (Moody, 2007).

\section{Discussion and Conclusion: Two Interpretations of Changing Neoliberal Rhetoric}

When Stiglitz (2008) said that neoliberals have no real interest in helping poor people but instead promote the market solution only to advance their own interests, he was implicitly suggesting, not just that their philosophy doesn't work, but that they are disingenuous. It is difficult to empirically test this hypothesis using a time-series analysis because relevant contextual elements have changed as the world has moved from the industrial to the post-industrial age. For example, in the late 20th century, the Internet forced countries with different cost structures to trade with each other and integrate their supply chains. At least one mainstream line of reasoning suggests that rich countries will be disadvantaged by this form of organization in what some have described as a race to a rising bottom (e.g. Spulber, 2007; Moody, 2007). Neoliberals are well poised to point out that there is nothing wrong with their philosophy but the situation has worsened for G20 countries and the best that can now be hoped for is that ordinary people can maintain their living standard. Hence, according to them at least, the neoliberal message has had to be attenuated. In light of the Stiglitz charge of disingenuousness, there are two possible ways to interpret the changing neoliberal message. First, wealthy and powerful people want others to adopt an ideology that will only benefit them and which they know will not work for anyone else. Second, quintessential neoliberalism really does work for everybody; and, a rising tides does lift all boats (including dinghies). The question for researchers is how to distinguish between these competing interpretations of the changed message.

The key to resolving the two-interpretations dilemma lies in finding data about the impact of neoliberal policies in circumstances where those policies have been applied in the industrial age. Such data exist and are briefly reviewed here. For example, when Reagan left office in 1985, he had extended the principle of the market to areas of society where it had never been before and the impact of his philosophy had, at that time, been felt. Mishel et al., (2009) provide and analyse data about class mobility and affluence through the 1980s. Some of their key findings include: the top one percent of American wage earners had a 324 percent increase in their annual earnings between 1979 
and 1989 whereas the bottom 90 percent had a 16 percent increase in their earnings over the same period; from 1983 until 1989 the median annual growth in productivity in the US economy was 1.6 percent per year and the median annual increase in compensation was 0.2 percent per year ${ }^{5}$; and, racial differences in annual median family incomes for 1979 to 1989 where 0.7 percent for whites, 0.6 percent for blacks and, 0.0 percent for Hispanics. Percentage-point changes for non-wage income sources (i.e. dividends paid on shares on sale of property etc.) reflect proportions for wage-related income but have greater magnitudes of difference (Mishel et al., 2009). From 1979 to 1989 the effective Federal tax rate declined for American households but the trend differentially impacted each income group. For example, from 1979 to 1989, the lowest 20 percent of income earners received a federal tax decrease of 0.1 percent (i.e. from 8 percent to 7.9 percent) whereas the top 1 percent of income earners received a tax decrease of just over 8 percent (i.e. from 37 percent to 28.9 percent).

In light of data about US society during the 1980s, it appears that explanations which invoke foreigners eating our lunch as the reason for neoliberal failure are inadequate. It is therefore argued here that the Stiglitz account of the origin and purpose of neoliberalism is closer to the mark than the neoliberalism account. This conclusion requires that key metaphors about the unbridled application of the market principle be revised. One such revision is suggested here-a rising tide lifts the big boats and may swamp the others.

\section{REFERENCES}

Bamber, G. J., Lansbury, R., \& Wailes, N. (2011). International comparative employment relations: Globalization and change (5th ed.). Los Angeles, CA: Sage.

Blair, T. (2000). Speech by the Prime Minister of Great Britain and Northern Ireland at the World Economic Forum in Davos, Switzerland. Reported on BBC news on the 28th February.

Braedley, S., \& Luxton, M. (2010). Neoliberalism and everyday life. Montreal: McGill-Queens University Press.

Briggs, C. (2005). Strikes and lockouts in the antipodes: Neoliberal convergence in Australia and New Zealand. New Zealand Journal of Employment Relations, 30, 21-35.

Brodie, J. (2007). Reforming Social justice in Neoliberal Times. Studies in Social Justice, 1, 93-107.

Cerny, P. G. (2007). Paradoxes of the competition state. The dynamics of political globalization. Government and Opposition, 32, 251-307. doi:10.1111/j.1477-7053.1997.tb00161.x

Chrétien, J. (1995). Allocution a un déjeuner de la conférence sur la mondialisation de l'économie. University of Sherbrook on July 14 on the occasion of the 3rd Annual Summit of the G7.

Connell, R. (2010). Understanding neoliberalism. In S. Braedley, \& M. Luxton (Eds.), Neoliberalism and everyday life (pp. 22-36). Montreal: McGill-Queens University Press.

Duncan, J. (1999). Management ideas and actions. New York: Oxford University Press.

Godard, J. (2011). Industrial relations, the economy and society (4th ed.). Warren, MI: Captus Press.
Gould, A. M. (2010). The Americanization of Australian workplaces. Labour History, 51, 363-388. doi:10.1080/0023656X.2010.508373

Hall, R. (2006). Industrial relations: A Current Review. Thousand Oaks, CA: Sage.

Hawke, R. J. L. (1984). Australia and Japan. 9th Annual Boyer Lecture held at the UNSW in Sydney.

Hawke, R. J. L. (1985). Speech to the center for European policy studies held in Brussels on 4-10 February. Commonwealth Record.

Hayek, F. A. (1944). The road to serfdom. Chicago: University of Chicago Press.

Howard, J. (1997). Strength not size. Howard's way. In D. Shanahan (Ed.), The Australian (p. 7).

Katz, H., \& Darbishire, O. (2000). Converging divergences. Worldwide changes in employment systems. New York: Cornell University Press.

Key, J. (2008). Interview with the Prime Minister of New Zealand given to Sunday Profile. ABC Australia.

Kennedy, J. F. (1963). Remarks in heber springs, arkansas, at the dedication of greers ferry dam. URL (last checked 7 April 2007). http://www.presidency.ucsb.edu/ws/index.php?pid=9455

Kersley, B., Alpin, C., Forth, J., Bryson, A., Bewley, H., Dix, G., \& Oxenbridge, S. (2006). Inside the workplace: Findings from the 2004 workplace relations survey. New York: Routledge.

Kochan, T. R., Lansbury, R., \& McDuffy, J. (1997). After lean production. Evolving employment practices in the world auto industry. New York: ILR Press.

Lange, D. (1984). The genesis of the commercialization strategy: From think big to privatization. Policy Document for the New Zealand Labour Party.

Marginson, S. (1997). Markets in education. Sydney: Allen and Unwin.

Mishel, L., Bernstein, J., \& Shierholz, H. (2009). The state of working America. 2008-2009. New York: Economic Policy Institute (Cornell University Press).

Moody, K. (2007). US labour in trouble and transition. The failure of reform from above. The promise of revival from below. New York: Verso.

Murray, C. (2012). Coming apart. The state of white America, 19602010. New York: Crown Forum.

Ong, A. (2007). Neoliberalism as expectation. Durham and London: Duke University Press.

Rannie, A., \& Fairbrother, P. (2006). Globalization, state and labour. London: Routledge.

Reagan, R. (1987). Speech given by the president of the United States at the Whitehouse.

Reagan, R. (1985). Second inaugural presidential address.

Stiglitz, J. (2008). The end of Neoliberalism. Project syndicate. http://www.project-syndicate.org/commentary/the-end-of-neo-liberal ism

Spulber, D. (2007). Global competitive strategy. New York: Cambridge University Press. doi:10.1017/CBO9780511841651

Thatcher, M. (1985). Interview given by the Prime Minister of Great Britain and Northern Ireland for London Weekend Television.

Tickell, A., \& Peck, J. (2003). Making global rules: Globalization or neoliberalisation. In J. Peck, \& H. Yeung, (Eds.), Remaking the global economy (pp. 163-182). London: Sage. doi:10.4135/9781446216767.n10

Wailes, N. (2000). Economic changes and domestic industrial relations institutions: Towards a theoretical model. Journal of Industrial Relations, 42, 214-233. doi:10.1177/002218560004200204

\footnotetext{
$\overline{{ }^{5} \text { Suggesting that workers generally had to work } 16 \text { percent harder each year }}$ to get a 0.2 percent wage increase.
} 